\title{
MEASUREMENT OF TOXIC METAL CONTAMINATION, PHENOLIC AND FLAVONOID CONTENTS, ANTICANCER, ANTIMICROBIAL AND ANTIOXIDANT ACTIVITIES OF DIETARY AND MEDICINAL PLANT JUGLANS REGIA L.
}

\author{
AZHAR, N. ${ }^{1}-$ KHAN, M. Q. ${ }^{1}-$ RIAZ, M. $^{2}-$ HUSSAIN, M. A. ${ }^{3 *}$ - DAR, M.E. U. I. ${ }^{1}-$ SHAHEEN, H. ${ }^{1}-$ \\ BIBI, A. ${ }^{4}-$ SWATI, J. ${ }^{1}-$ MUNIR, A. ${ }^{5}-$ ALTAF, H. ${ }^{1}-$ HABIB, T. ${ }^{1}$ \\ ${ }^{I}$ Department of Botany, University of Azad Jammu \& Kashmir, Muzaffarabad-13100, Pakistan \\ ${ }^{2}$ Department of Chemistry, University of Azad Jammu \& Kashmir, Muzaffarabad-13100, Pakistan \\ ${ }^{3}$ Department of Biotechnology, Mirpur University of Science and Technology (MUST) \\ Mirpur-10250, AJK, Pakistan \\ ${ }^{4}$ Department of Botany, Women University of Azad Jammu \& Kashmir, Bagh-12460, Pakistan \\ ${ }^{5}$ Department of Biotechnology, University of Azad Jammu \& Kashmir, Muzaffarabad-13100, Pakistan \\ *Corresponding author \\ e-mail: scholar.altaf@gmail.com
}

(Received 6 ${ }^{\text {th }}$ Dec 2017; accepted 27 $7^{\text {th }}$ Feb 2018)

\begin{abstract}
Medicinal plants have a proven long history for their effective use to prevent and treat diseases. During the recent decades, the modern drug discovery approaches have refocused on traditional medicinal plants because of their higher contribution for providing new drugs, drug candidates, novelty and mechanism insights. Juglans regia $\mathrm{L}$. is very famous for providing precious and medicinal dry fruits which are extensively being used in many parts of the world. In this study four parts of J. regia i.e. fruits, leaves, stem bark and green husk were investigated for metal contamination by using atomic absorption spectroscopy and found that $\mathrm{Cd}$ contamination in its fruits, $\mathrm{Cu}$ and $\mathrm{Mg}$ concentration in all parts of $J$. regia (fruits, leaves, stem bark and green husk) were critically above the standard permissible limits. Methanolic extracts of various parts for J. regia were screened for antimicrobial activities against twelve different human pathogens which indicated that fruits, leaves, stem bark and green husk were proved to be potential source of antimicrobial activities in comparison to the standard clinical drugs i.e. ciprofloxacin and nystatin which was used as positive control. Whereas, J. regia fruit had potent antioxidant properties with $\mathrm{IC}_{50}$ value of $6.938693 \mathrm{mg} \mathrm{mL}^{-1}$. Total phenolic contents were ranged from 12.6987 to $31.9685 \mathrm{mg}$ of $\mathrm{GA} \mathrm{g}^{-1}$ whereas, highest flavonoid contents were found in the fruit's extract which was $25.8231 \mathrm{mg} \mathrm{g}^{-1}$ and lowest in leaves extract of J. regia i.e. $7.2861 \mathrm{mg} \mathrm{g}^{-1}$. Breast cancer is the top most prevalent cancer in women worldwide and is responsible for nearly $58 \%$ of all cancer deaths. The Juglans regia fruits, green husk, stem bark and leaves showed promising antiproliferative activities against MCF-7 breast cell lines. Fruit of J. regia was proved to be more potent as compared to other parts screened with highest antiproliferative activity i.e. $\mathrm{GI}_{50} 1.581722$ at conc. $1 \mathrm{mg} / \mathrm{mL}$.
\end{abstract}

Keywords: Juglans regia, toxic metals, antimicrobial, antioxidants, anticancer, total phenolic, flavonoids

\section{Introduction}

Therapeutic plants are the manufacturing plants of medicinal phytochemicals which carry the nature designed unmatched structural novelties and properties that bind to bio macromolecules for the critical modulations to regulate disorders. These therapeutic plants are as yet being utilized extensively by rural people as natural remedies to treat diseases without legitimate standardization or regulations and that which poses genuine danger to human health especially, because of unwanted metals defilements and lack of 
dosage standardization that results into various unwanted interactions with bio macromolecules and toxins. Emergence of drug resistance (primarily due to wicked adaptive native nature of microorganisms and unregulated excessive use of antiinfectious drugs), emergence of new diseases, insufficiencies of the existing drugs and poor outcomes of drug discovery programs have created a highly critical emergency for the discovery and development of new antimicrobial drugs, templates and leads (Gutmann et al., 1998; Cohen, 1992). Natural biological processes essentially require energy which comes through oxidation responses but imbalanced and excessive oxidation due to reactive oxygen species (ROS). ROS are highly reactive species which unwantedly and harmfully modulate the structures and hence the functions of bio macromolecules including nucleic acids, proteins and lipids. Subsequently, this give birth to various biological disorders including deadly tumors, neurodegenerative, cardiovascular disorders, cataracts, diabetes, aggravations and atherosclerosis (Aruoma, 1998). Nature has unmatched metabolic designing and manufacturing enzymatic machinery which provide new drugs, leads, knowledge and inspiration for the design and discoveries of the medicinal and organic chemists for their efforts of new drug development as well as synthetic methodologies to fight diseases including caused by the deadly infections and reactive free radicals. Medicinal plants have been used for a long time in the treatment of various diseases. In today's World over $70 \%$ of the clinical molecular drugs are either natural products based or derived (Recio et al., 1989; Silver et al., 1993). Pakistan is naturally blessed with diverse climatic ranges that start from northern Himalayas to southern costal condition which lies after middle hot range. This diverse climatic range in turns provides diverse and rich fauna and flora contain numerous medicinal species. These medicinal species are being used by the local are traditional herbal medicines since long time. Pakistan has rich history, society and learning of utilizing these therapeutic species to treat and prevent different diseases. Thus, Pakistani is a major producer, user and supplier of medicinal species (Saeed et al., 2012). Biological screening of these therapeutic plants is the key beginning stage for the discovery of biologically relevant natural products from these medicinal plants. Unwanted and excessive generation of free radicals based diseases poses the urgent needs for the discovery of new antioxidant molecules and plants made, phenols, flavonoids, tannins and anthocyanidins are the most promising skeletons for the new drug discovery and development against these diseases (Saeed et al., 2012; Peschel et al., 2006).

Walnut (J. regia) possesses high medicinal properties because of its diverse natural chemical constituents and its mineral contents. Its different parts (leaves, barks and natural products) have been and are being utilized as a part of traditional herbal medicinal products. Leaves of J. regia are being used for treating venous inadequacy, hemorrhoids, hypoglycemia, and looseness of the bowels, microbial infections, dental caries contamination and strums bruises. Its leaves also treat skin diseases, purify the blood and helminthic, and are calming, astringent and depurative. They are being used as major herbal component for the treatment of clogging, endless hacks, asthma, looseness of the bowels, dyspepsia astringency, keratosis, diarrhea, hypoglycemia, sinusitis, cool and stomach throb (Mouhajir et al., 2008; Vaidyaratnam, 2005). Green husk of $J$. regia has cancer preventing properties and is antifungal, astringent, wart vendor impacts and treats skin diseases (Noumi et al., 2010; Amaral et al., 2003). Stem bark of J. regia is used to treat gastric, liver and lung tumor (Liu et al., 2004; Baytop, 1999). People utilized the fruits of J. regia as pharmaceutical to recuperate intestinal 
sickness, enhance memory shortages in transgenic mouse model of Alzheimer's ailment. It is being used as insect lithic, diuretic, anthelmintic and stimulant as well as for the treatment of low back torment, incessant pee, shortcoming of legs, unending hack, asthma and clogging (Tagarelli et al., 2010).

Keeping in view the importance of $J$. regia as dietary and folk remedial source, this study was aimed to assess the toxic metal contaminations, antimicrobial properties, antioxidant potential, phenolic contents and flavonoids contents of locally grown plants.

\section{Material and methods}

\section{Plant material collection and preparation}

Juglans regia L. is locally known as Akhrot and was collected from Rayala, Dhirkot, Azad Kashmir, Pakistan. Fruits, leaves, green husk and stem bark of Juglans regia L. were used to investigate the toxic metal contaminations, antimicrobial, antioxidant, total phenolic and flavonoids contents. The samples were carefully collected, separated and packed into bags and then transported to the laboratory for investigation.

\section{Preparation of extract}

Each part of the plant was shade dried for 10 days at room temperature then, were ground into fine powder with the help of electrical grinder and were stored at $4{ }^{\circ} \mathrm{C}$ for further studies. The $100 \mathrm{~g}$ dried powder of each part of J. regia was separately macerated in $500 \mathrm{~mL}$ of methanol and kept at room temperature $\left(25 \pm 2{ }^{\circ} \mathrm{C}\right)$ for 10 days. After maceration period, the solvent extracted material was filtered. These extracts of plants portions were dried on rotary evaporator at low temperature $\left(60^{\circ} \mathrm{C}\right)$ and reduced pressure.

\section{Acid digestion, sample preparation for the estimation of metal contaminations}

One gram of dry powder of each part of J. regia was subjected to acid digestion for the estimation of their metal contaminations. $1 \mathrm{~g}$ of powder of each part of $J$. regia was taken in a glass beaker and $6 \mathrm{~mL}$ of concentrated nitric acid $\left(\mathrm{HNO}_{3}\right)$ and hydrogen peroxide $\left(\mathrm{H}_{2} \mathrm{O}_{2}\right)$ were added (in $\left.2: 1 \mathrm{~V} \mathrm{~V}^{-1}\right)$. Mixture was stirred slowly at room temperature. The glass beaker was covered with a petri dish and heated at $70{ }^{\circ} \mathrm{C}$ for $3 \mathrm{~h}$. Small volumes of $\mathrm{HNO}_{3}$ and $\mathrm{H}_{2} \mathrm{O}_{2}$ were added to this mixture along with continuous heating at $70{ }^{\circ} \mathrm{C}$ till a clear solution was obtained. The excess of acid was evaporated and a semi dry mass was obtained. This semi dry mass was solubilized in $10 \mathrm{~mL} \mathrm{HNO}_{3}$ $(0.1 \mathrm{M})$ and was transferred to a $50 \mathrm{~mL}$ volumetric flask. Total volume of solution was made $50 \mathrm{~mL}$ with the addition of distilled water.

\section{Specification of AAS}

Operating parameters of Atomic Absorption Spectrophotometer (AAS) AAnalyst ${ }^{700}$ was used in the analysis of trace metals using respective Wavelength in the range of 190-900 nm, Diffraction grating: 1800 lines $\mathrm{mm}^{-1}$ blazed at $236 \mathrm{~nm}$ and $597 \mathrm{~nm}$, Grating area: $64 \times 72 \mathrm{~mm}$, reciprocal linear dispersion: $1.6 \mathrm{~nm} \mathrm{~mm}^{-1}$ (nominal), Focal length: $267 \mathrm{~mm}$, Spectral bandwidths: $0.2,0.7$ and $2.0 \mathrm{~nm}$, dual height, motorized slit drive for automatic slit selection with wide-range segmented solid-state detector. 
AAnalyst ${ }^{700}$ used winlab 32 program to automatically calculate the mean of three reading of each samples of $J$. regia for each metal.

\section{Determination of antimicrobial activity}

Preparation of sample solutions for anti-microbial activity

$10 \mathrm{mg}$ of dried methanolic extract of each part of J. regia was dissolved in $1 \mathrm{~mL}$ of respective solvent in 5 separate air tight eppendorf tubes to prevent contamination and were kept for four days to ensure solubility.

\section{Test microorganisms}

Twelve common human pathogens viz., three gram positive bacteria (Staphylococcus aureus, Proteus vulgaris and Bacillus subtilis), four gram negative bacteria (Pseudomonas aeruginosa, Klebsiella pneumoniae, Escherichia coli and Bordetella bronchiseptica), three fungi (Aspergillus flavus, Fusarium solani, Rhizopus stolonifer) and two yeasts (Saccharomyces cerevisiae, Candida albicans) were used to assess the antimicrobial properties of the selected plant's parts.

\section{Antimicrobial bioassay}

In vitro screening of the methanolic extracts of four parts of J. regia was performed by disc diffusion method as described by (Scorzoni et al., 2007). Two series of experiments were conducted for testing the antibacterial, antifungal and anti-yeast activities of these extracts. These extracts were tested for their antimicrobial activities with reference to standard reference antibiotics (ciprofloxacin and nystatin). All the steps, inoculums, petri dishes, preparation of dilution were performed under aseptic conditions. The plates containing bacterial culture were incubated for $24 \mathrm{~h}$ at $37{ }^{\circ} \mathrm{C}$ whereas, fungi and yeast dilution were incubated at $25^{\circ} \mathrm{C}$ for $72 \mathrm{~h}$. After incubation period, all plates were examined for the presence of zone of inhibition (mm) to assess their antimicrobial activity. Each experiment was performed in triplicates.

\section{Determination of antioxidant activity}

\section{Sample preparation for antioxidant activity}

$10 \mathrm{mg}$ of dried methanolic extract of each part of J. regia was dissolved in $2 \mathrm{~mL}$ of methanol in 5 separate test tubes. DPPH radical cation decolorization assay was used to evaluate the antioxidant properties of the methanolic extracts of J. regia.

\section{DPPH decolorization assay for antioxidant activities}

DPPH (1,1-diphenyl-2-picrylhydrazyl) scavenging activities were analyzed to evaluate the antioxidant properties of the extracts of four parts of J. regia according to the method (Amarowicz et al., 2004). DPPH stock solution was prepared by reacting potassium per sulphate and DPPH (33.75 mg potassium persulphate $+64.8 \mathrm{mg}$ of DPPH in $100 \mathrm{~mL}$ of distilled water) and allowed to stand in dark for $16 \mathrm{~h}$ to generate DPPH radical acation. Absorbance of the standard solutions was recorded at $734 \mathrm{~nm}$ (Ao Control $_{\text {) }}$ after diluting with water up to respective volume. For percent scavenging activity (\% RSC) of each extract, $1 \mathrm{~mL}$ of DPPH and $200 \mu \mathrm{L}$ of each extract concentration $(1 \mathrm{mg}$, $2 \mathrm{mg}$ and $5 \mathrm{mg}$ crude extracts each dissolved in per $\mathrm{mL} \mathrm{MeOH}$ ) were mixed and then 
followed by the addition of $1.8 \mathrm{~mL}$ water to make the volume of reaction mixture up to $3 \mathrm{~mL}$. The absorbance (Ai) of each reaction was recorded for each sample at $734 \mathrm{~nm}$ and the blank used for each sample contained $2.8 \mathrm{~mL}$ of distilled water and $200 \mu \mathrm{L}$ of extract solutions. All measurements were taken in triplicates. The percentage radical scavenging activities (\% RSC) were calculated using the formula:

$$
\% \mathrm{RSC}=\frac{\left[\mathrm{Ao}_{\text {Control }}-\mathrm{Ai}_{\text {Sample }}\right]}{\mathrm{Ao}_{\text {Control }}} \times 100
$$

\section{Total phenolic and flavonoid contents}

Total phenolic contents in four parts of J. regia were determined by Folin-Ciocalteu method (Jimoh et al., 2007). Phenolic contents were expressed as gallic acid (GA) equivalents ( $\mathrm{mg}$ of $\mathrm{GA} \mathrm{g}^{-1}$ of extract). Total flavonoid contents in four parts of J. regia were measured as described previously by Piccolella et al. (2008). The total flavonoid contents were calculated as rutin equivalents (mg of Rutin $\mathrm{g}^{-1}$ of extract).

\section{Anticancer activity}

\section{Cell lines and cell viability assay}

Human breast disease (MCF-7) cells were obtained from ATCC (Rockville, MD). All cells were cultured in a humidified $5 \% \mathrm{CO}_{2}$ environment at $37{ }^{\circ} \mathrm{C}$ in an incubator and refined in RPMI-1640 medium supplemented with $10 \%$ warm inactivated infant calf serum, $100 \mathrm{IU} / \mathrm{mL}$ penicillin and $100 \mu \mathrm{g} / \mathrm{mL}$ streptomycin. Restraint of cell multiplication by the walnut extracts was measured by the MTT test. Rapidly, PC3 cells were plated in 96-well culture plates $(1 \times 105$ cells/well $)$ independently. After $24 \mathrm{~h}$ incubation, cells were treated with Juglans regia crude extracts $(0.5 \mathrm{mg} / \mathrm{mL}$ and $1 \mathrm{mg} / \mathrm{mL}$; eight wells for every focus) for $24 \mathrm{~h}$; MTT concentration $(5 \mathrm{mg} / \mathrm{mL})$ was then poured to each well. After $4 \mathrm{~h}$ incubation, the formazan particles were kept in dimethyl sulfoxide $(100 \mu \mathrm{L})$ and afterward the absorbance was measured in an ELISA at $570 \mathrm{~nm}$. Cell reasonability proportion was computed by following formula:

$$
\text { Cell viability }(\%)=\frac{[\mathrm{Ac}-\mathrm{At}]}{\mathrm{Ac}} \times 100
$$

where Ac is the absorbance of control cell and At absorbance of treated cells, respectively.

Cytotoxicity was expressed as the concentration of the extracts in growth inhibition of cell by $50 \%$ ( $\mathrm{GI}_{50}$ value).

\section{Statistical analysis}

All values were expressed as mean \pm standard error of means. By using one-way analysis of variance (ANOVA) technique (Steel et al., 1980). The mean was compared by using LSD at $5 \%(0.05)$ probability level by using statistic 8.1 software. 


$$
\text { - } 2312 \text { - }
$$

\section{Results and discussion}

\section{Metal contaminations of J. regia}

During current study the contaminations of six metals $(\mathrm{Cd}, \mathrm{Cr}, \mathrm{Cu}, \mathrm{Mn}, \mathrm{Mg}$ and $\mathrm{Zn}$ ) in four parts of J. regia extracts using Atomic Absorption Spectrophotometry (AAS) were investigated. The wave length were taken to measure the concentrations of each metal in each extract and the mean concentration of each metal in each extract (in $\mathrm{mg} \mathrm{L}^{-}$ ${ }^{1}$ ) are given in Table 1 .

Table 1. Metal concentration in J. regia for the estimation of metal contamination $(\mathrm{mg} / \mathrm{L})$

\begin{tabular}{c|c|c|c|c|c|c|c}
\hline$\#$ & $\begin{array}{c}\text { Part used } \\
\text { (Analyte absorbance) }\end{array}$ & $\begin{array}{c}\mathbf{C d} \\
\mathbf{( 2 2 8 . 8} \mathbf{~ n m})\end{array}$ & $\begin{array}{c}\mathbf{C r} \\
\mathbf{( 3 5 7 . 9} \mathbf{~ n m})\end{array}$ & $\begin{array}{c}\mathbf{C u} \\
\mathbf{( 3 2 4 . 8} \mathbf{~ n m})\end{array}$ & $\begin{array}{c}\text { Mn } \\
\mathbf{( 2 7 9 . 5} \mathbf{~ n m})\end{array}$ & $\begin{array}{c}\mathbf{M g} \mathbf{( 2 8 5 . 2} \\
\mathbf{n m})\end{array}$ & $\begin{array}{c}\mathbf{Z n} \\
\mathbf{( 2 1 3 . 9} \mathbf{~ n m})\end{array}$ \\
\hline 1 & Fruits & 4.872 & 0.156 & 19.84 & 0.469 & 105.5 & 1.139 \\
2 & Leaves & 0.323 & 0.047 & 4.555 & 0.313 & 124.9 & 0.417 \\
3 & Stem bark & 0.037 & 0.815 & 3.612 & 0.260 & 113.0 & 0 \\
4 & Green husk & 0.037 & 0.079 & 4.175 & 0.110 & 94.0 & 0 \\
\hline
\end{tabular}

The present study reports the estimation of metal contaminations of six metals, namely; $\mathrm{Cd}, \mathrm{Cr}, \mathrm{Cu}, \mathrm{Mn}, \mathrm{Mg}$ and $\mathrm{Zn}$ in selected parts of J. regia and were compared with the standard permissible limits (SPLs) by the FAO/WHO to evaluate their potential impact on the health. These studies indicated that $\mathrm{Cd}$ concentration in fruits and leaves, $\mathrm{Cr}$ concentration in fruits, stem bark and green husk, $\mathrm{Cu}$ and $\mathrm{Mg}$ concentration in all parts of $J$. regia (fruits, leaves, stem bark and green husk) were above the standard permissible limits, Mn concentration in fruits and leaves and $\mathrm{Zn}$ concentration in all plant's parts of $J$. regia were below the standard permissible limits, $\mathrm{Zn}$ was not found in stem bark and green husk of J. regia. The concentration of each metal in all four tested parts were also represented in Fig. 1.

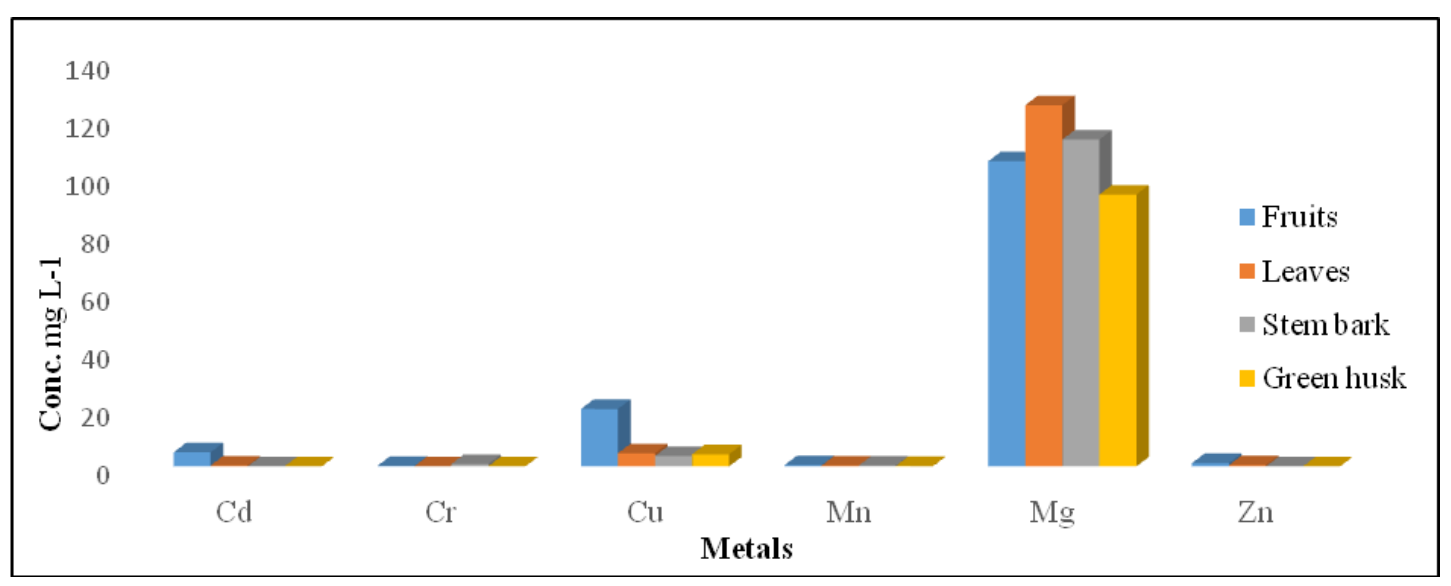

Figure 1. Metal contaminations in four parts of J. regia

Higher Cd concentration in fruits and leaves of J. regia was the major contributing reason to the potential health risk in Nanning, China (Cui et al., 2004) and in Boolaroo, Australian (Kachenko and Singh, 2006). The main contaminations of Cd were reported in grape, spinach and celery. Therefore, these results should be used as important 
guidelines for the producers, traders, consumers and regulatory authorities. Unfortunately, in these areas there are no regulatory practices for the assessment of these walnut fruits which are extensively used by the local inhabitants and sold in the market throughout the country. The amount of $\mathrm{Cu}$ was critically above the standard permitted limit which indicate the high composition of the $\mathrm{Cu}$ in these selected area that ultimately accumulate in the flora, fruits and vegetables. It also worth noticing, that $\mathrm{Zn}$ was also omitted in the samples of J. regia. The standard acceptable limits (SPLs) of metal contamination (in dietary and medicinal species) are: $\mathrm{Cd}=0.06 \mathrm{mg} \mathrm{L}^{-1}, \mathrm{Cr}=0.05$ $\mathrm{mg} \mathrm{L}^{-1}, \mathrm{Cu}=0.1 \mathrm{mg} \mathrm{L}^{-1}, \mathrm{Mn}=0.26 \mathrm{mg} \mathrm{L}^{-1}, \mathrm{Mg}=50 \mathrm{mg} \mathrm{L}^{-1}$ and $\mathrm{Zn}=5.0 \mathrm{mg} \mathrm{L}^{-1}(\mathrm{Singh}$ et al., 2010).

\section{Antimicrobial activities of J. regia}

Antibacterial activities of the methanolic extracts were assessed by the disc diffusion method against twelve common human pathogens. Zone of inhibition (mm) of all these extracts were mentioned in Table 2.

Table 2. Anti-microbial activity of methanolic extracts of four parts J. regia against tested human pathogens

\begin{tabular}{c|c|c|c|c|c|c|c}
\hline \multicolumn{7}{c}{ Mean diameter of zones of inhibition $(\mathbf{m m}) \pm$ standard error of means (S.E.M) } \\
\hline$\#$ & Pathogens & Fruits & Stem bark & Green husk & Leaves & Ciprofloxacin & Nystatin \\
\hline 1 & S. aureus & $14.33_{\mathrm{a}} \pm 0.33$ & $13.33_{\mathrm{b}} \pm 0.67$ & $11.67_{\mathrm{d}} \pm 0.33$ & $10.33_{\mathrm{b}} \pm 0.33$ & $33.33_{\mathrm{a}} \pm 0.33$ & --- \\
2 & P. aeruginosa & $13.67_{\mathrm{a}} \pm 0.33$ & $12.67_{\mathrm{b}} \pm 0.33$ & $18.16_{\mathrm{a}} \pm 0.28$ & $10.67_{\mathrm{b}} \pm 0.33$ & $33.33_{\mathrm{a}} \pm 0.33$ & --- \\
3 & K. pneumonia & $10.67_{\mathrm{bc}} \pm 0.33$ & $10.33_{\mathrm{c}} \pm 0.33$ & $13.33_{\mathrm{bc}} \pm 0.67$ & $8.67_{\mathrm{c}} \pm 0.33$ & $29.67_{\mathrm{b}} \pm 0.33$ & --- \\
4 & P. vulgaris & $8.67_{\mathrm{de}} \pm 0.33$ & $15.16_{\mathrm{a}} \pm 0.28$ & $12.67_{\mathrm{bcd}} \pm 0.3$ & $7.67_{\mathrm{c}} \pm 0.33$ & $32.33_{\mathrm{a}} \pm 0.67$ & --- \\
5 & E. coli & $13.33_{\mathrm{a}} \pm 0.67$ & $11.33_{\mathrm{c}} \pm 0.33$ & $12.33_{\mathrm{cd}} \pm 0.67$ & $19.33_{\mathrm{a}} \pm 0.57$ & $20.67_{\mathrm{e}} \pm 0.33$ & --- \\
6 & B. subtilis & $7.67_{\mathrm{e}} \pm 0.33$ & $16.33_{\mathrm{a}} \pm 0.57$ & $0.00_{\mathrm{f}} \pm 0.00$ & $0.00_{\mathrm{d}} \pm 0.00$ & $25.33_{\mathrm{c}} \pm 0.57$ & --- \\
7 & B. bronchiseptica & $9.67_{\mathrm{cd}} \pm 0.00$ & $13.67_{\mathrm{b}} \pm 0.33$ & $0.00_{\mathrm{f}} \pm 0.00$ & $0.00_{\mathrm{d}} \pm 0.00$ & $23.16_{\mathrm{d}} \pm 0.28$ & -- \\
8 & A. flavus & $0.00_{\mathrm{f}} \pm 0.00$ & $0.00_{\mathrm{d}} \pm 0.00$ & $13.67_{\mathrm{b}} \pm 0.33$ & $0.00_{\mathrm{d}} \pm 0.00$ & --- & $20.67_{\mathrm{d}} \pm 0.33$ \\
9 & F. solani & $0.00_{\mathrm{f}} \pm 0.00$ & $0.00_{\mathrm{d}} \pm 0.00$ & $0.00_{\mathrm{f}} \pm 0.00$ & $0.00_{\mathrm{d}} \pm 0.00$ & --- & $28.33_{\mathrm{b}} \pm 0.33$ \\
10 & R. stolonifer & $11.67_{\mathrm{b}} \pm 0.33$ & $0.00_{\mathrm{d}} \pm 0.00$ & $0.00_{\mathrm{f}} \pm 0.00$ & $0.00_{\mathrm{d}} \pm 0.00$ & --- & $39.67_{\mathrm{a}} \pm 0.33$ \\
11 & S. cerevisiae & $0.00_{\mathrm{f}} \pm 0.00$ & $0.00_{\mathrm{d}} \pm 0.00$ & $0.00_{\mathrm{f}} \pm 0.00$ & $8.67_{\mathrm{c}} \pm 0.33$ & --- & $23.33_{\mathrm{c}} \pm 0.33$ \\
12 & C. albicans & $0.00_{\mathrm{f}} \pm 0.00$ & $10.66_{\mathrm{c}} \pm 0.57$ & $0.00_{\mathrm{f}} \pm 0.00$ & $0.00_{\mathrm{d}} \pm 0.00$ & --- & $11.67_{\mathrm{e}} \pm 0.33$ \\
\hline
\end{tabular}

Note: the means followed by same letters are non-significant

Results of the sensitivity tests were expressed as (0) for no sensitivity, (7-10 mm) for low sensitivity, (11-18 $\mathrm{mm}$ ) for moderate sensitivity and (>19 $\mathrm{mm})$ for high sensitivity. Fruit's extract of $J$. regia exhibited significant zone of inhibitory activities $(11-18 \mathrm{~mm})$; $14.33 \pm 0.33,13.67 \pm 0.3,13.33 \pm 0.67$ and $11.67 \pm 0.33$ against $S$. aureus, $P$. aeruginosa, E. coli and $R$. stolonifer, while it showed marginal activity against $K$. pneumonia, $P$. vulgaris, B. subtilis and B. bronchiseptica i.e. $8.67 \pm 0.33,8.67 \pm 0.33$, $7.67 \pm 0.33$ and $9.67 \pm 0.00$, respectively. The low sensitivity conferred by gram negative bacteria was due to composition of their cell wall as previous study of Parekh and Chanda (2007) depicted that gram negative bacteria were more resistant than gram positive bacteria against all the drugs tested. Fruit extract showed no activity against other tested microorganisms whereas, the extract of stem bark exhibited significant activity; $13.33 \pm 0.67,12.67 \pm 0.33,15.16 \pm 0.28,11.33 \pm 0.33,16.33 \pm 0.57$ and 13.67 \pm 0.33 against $S$. aureus, $P$. aeruginosa, $P$. vulgaris, E. coli, B. subtilis and $B$. 


$$
-2314-
$$

bronchiseptica, respectively, while other strains of tested microorganism were found to be resistant to stem bark extract of J. regia. The finding of Salar and Suchitra (2009) suggested that polar extract showed higher antimicrobial properties against tested microorganisms which are in line with the current study. Methanolic extract of the green husk of $J$. regia showed considerable activity against $S$. aureus $(11.67 \pm 0.33), P$. aeruginosa (18.16 \pm 0.28$)$, K. pneumonia (13.33 \pm 0.67$)$, P. vulgaris (12.67 \pm 0.33$), E$. coli $(12.33 \pm 0.67)$ and A. flavus $(13.67 \pm 0.33)$ whereas, B. subtilis, B. bronchiseptica, $F$. solani, $R$. stolonifer, $S$. cerevisiae and $C$. albicans were found to be resistant to green husk extract of $J$. regia. A. flavus was also inhibited by the extract used however all other fungal and yeast strains were found resistant as shown in Figures 2 and 3.

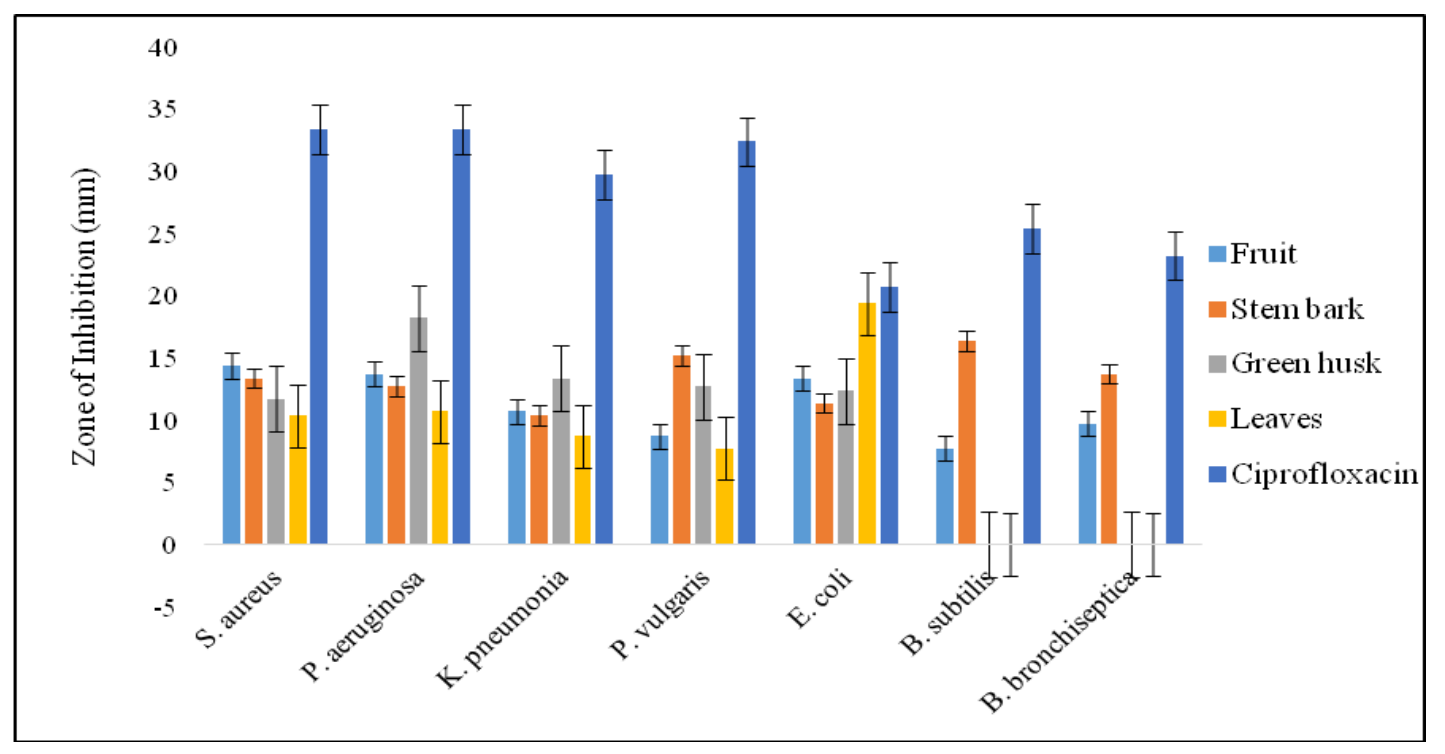

Figure 2. Antibacterial activities of the methanolic extract of J. regia

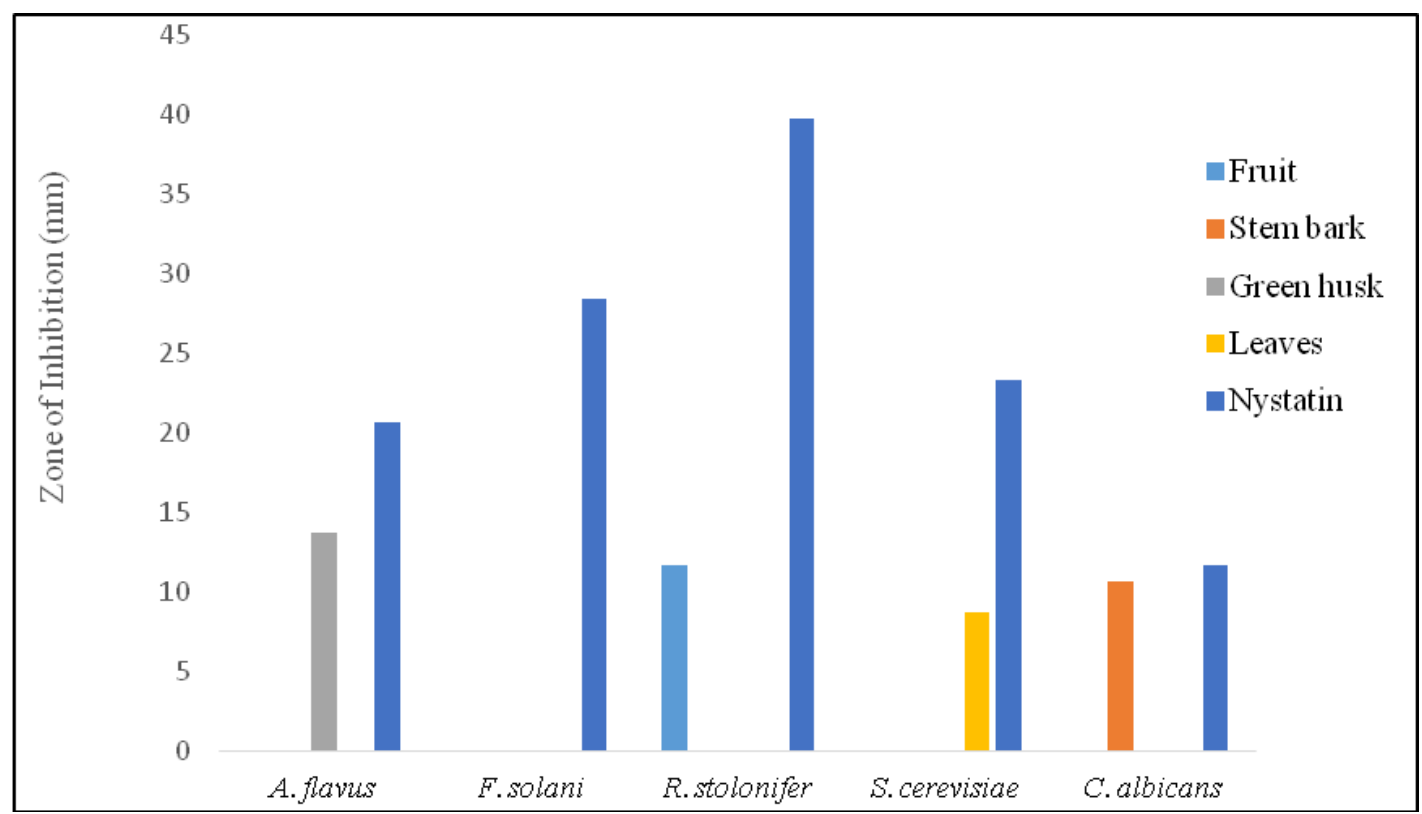

Figure 3. Antifungal activities of the methanolic extract of J. regia 
These results were in accordance with the previous studies which also deduced that plant extracts were more effective against bacteria than fungi (Mehmood et al., 2013). Methanolic extract of leaves of $J$. regia conferred high activity i.e. $19.33 \pm 0.57 \mathrm{~mm}$ against $E$. coli while, it showed low activity $(10.33 \pm 0.33,10.67 \pm 0.33,8.67 \pm 0.33,7.67$ \pm 0.33 and $8.67 \pm 0.33$ ) against $S$. aureus, $P$. aeruginosa, $K$. pneumonia, $P$. vulgaris and $S$. cerevisiae, respectively. Extract of its leaves was found inactive against other bacterial and fungal strains. These results were in harmony with the previous investigations of Naika et al. (2012). Moreover, the current study revealed that plant parts extracts were more active against gram positive bacteria as compared to gram negative bacteria tested due the fact that the outer membrane of the cell wall of gram negative bacteria acts as a barrier to many synthetic and natural antibiotics (Tortora and Funke, 2001).

\section{Antioxidant activities of J. regia}

Antioxidant properties of the methanolic extracts of four parts of $J$. regia under discussion were measured by DPPH radical decolorization assay. Three concordant readings were taken for each extract at $734 \mathrm{~nm}$ and mean (Ai) was calculated. Value of control (Ao) at $734 \mathrm{~nm}$ was 0.1 . The percentage radical scavenging activity (\% RSC) was calculated using the formula: $\% \operatorname{RSC}=\left[\left(\right.\right.$ Ao $\left.\left._{\text {Control }}-\mathrm{Ai}_{\text {Sample }}\right)\right] / \mathrm{Ao}_{\text {Control }} \times 100 \%$. All results for these methanolic extracts are summarized in Table 3. It was observed that the methanolic extract of $J$. regia fruit showed stronger free radical scavenging ability with $6.938693 \mathrm{mg} \mathrm{mL}^{-1} \mathrm{IC}_{50}$ value. Similarly, methanolic extracts of leaves, stem bark and green husk showed $9.224862 \mathrm{mg} \mathrm{mL}^{-1}, 8.901780 \mathrm{mg} \mathrm{mL}^{-1}$ and $13.862772 \mathrm{mg} \mathrm{mL}^{-1} \mathrm{IC}_{50}$, respectively. Methanol extracts are generally found to possess higher antioxidant activity because the polar solvents in extraction of all the phenolic compounds and that might be carrying the most of the bioactive compounds from plants (Fatima et al., 2007). Our results are graphically shown in Figure 4 including the $\mathrm{IC}_{50}$ values of all of methanolic extracts.

Table 3. Antioxidant activity of the methanolic extracts of four parts of J. regia

\begin{tabular}{|c|c|c|c|c|c|}
\hline \# & Part used & $1 \mathrm{mg} \mathrm{mL}^{-1}$ & $3 \mathrm{mg} \mathrm{mL}^{-1}$ & $5 \mathrm{mg} \mathrm{mL}^{-1}$ & $\mathrm{IC}_{50}$ \\
\hline 1 & Fruits & 35.26 & 39.29 & 42.13 & 6.938693 \\
\hline 2 & Leaves & 21.13 & 27.07 & 30.02 & 9.224862 \\
\hline 3 & Stem bark & 18.26 & 22.61 & 27.16 & 8.901780 \\
\hline 4 & Green husk & 10.16 & 17.24 & 24.02 & 13.862772 \\
\hline
\end{tabular}

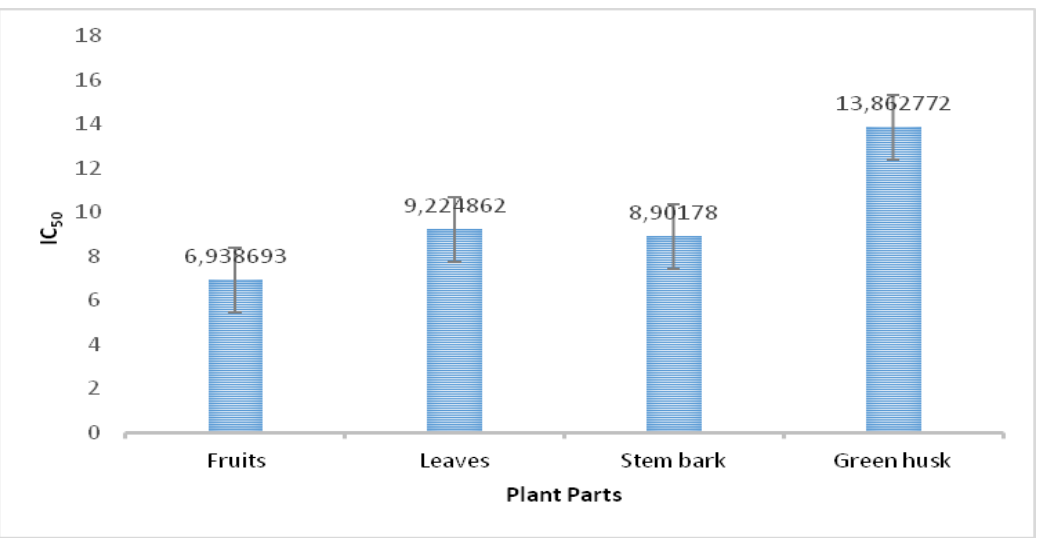

Figure 4. $I C_{50}$ values of the methanolic extracts of four parts of J. regia 


$$
-2316-
$$

\section{Phenolic contents of four parts of J. regia}

Total phenolic contents of methanolic extract of four parts of J. regia were assessed by using Folin-Ciocalteu phenol reagent and results are tabulated in Table 4. The values ranged from 12.6987 to $31.9685 \mathrm{mg} \mathrm{of} \mathrm{GA} \mathrm{g}^{-1}$ of extract. The highest value was recorded in the stem bark extract which was $31.9685 \mathrm{mg} \mathrm{GA} \mathrm{g}^{-1}$ and lowest value in green husk which was $12.6987 \mathrm{mg} \mathrm{GA} \mathrm{g}^{-1}$ (Fig. 5). The phenolic contents estimated in this studies were probably, responsible for the free radical-scavenging activity of $J$. regia. The phenolic compounds were attributed to the overall antioxidant activities, it is important to point out that during present study studies it was recorded that the relationship between antioxidant activities and amount of phenolic contents in all extracts which are also in agreement with the previous investigations (Anwar et al., 2013).

Table 4. Total phenolic contents of J. regia (in methanolic extracts of fruits, leaves, stem bark and green husk)

\begin{tabular}{c|c|c|c|c}
\hline$\#$ & Part used & Conc. Used & Absorbance & mg of GA g $^{-1}$ of extract \\
\hline 1 & Fruits & $2.5 \mu \mathrm{L}$ & 70.90 & $30.2689_{\mathrm{a}} \pm 3.46 \mathrm{a}$ \\
2 & Leaves & $2.5 \mu \mathrm{L}$ & 80.75 & $19.8762_{\mathrm{b}} \pm 2.32 \mathrm{~b}$ \\
3 & Stem bark & $2.5 \mu \mathrm{L}$ & 79.25 & $31.9685_{\mathrm{a}} \pm 4.33 \mathrm{a}$ \\
4 & Green husk & $2.5 \mu \mathrm{L}$ & 22.32 & $12.6987_{\mathrm{b}} \pm 1.74_{\mathrm{b}}$ \\
\hline
\end{tabular}

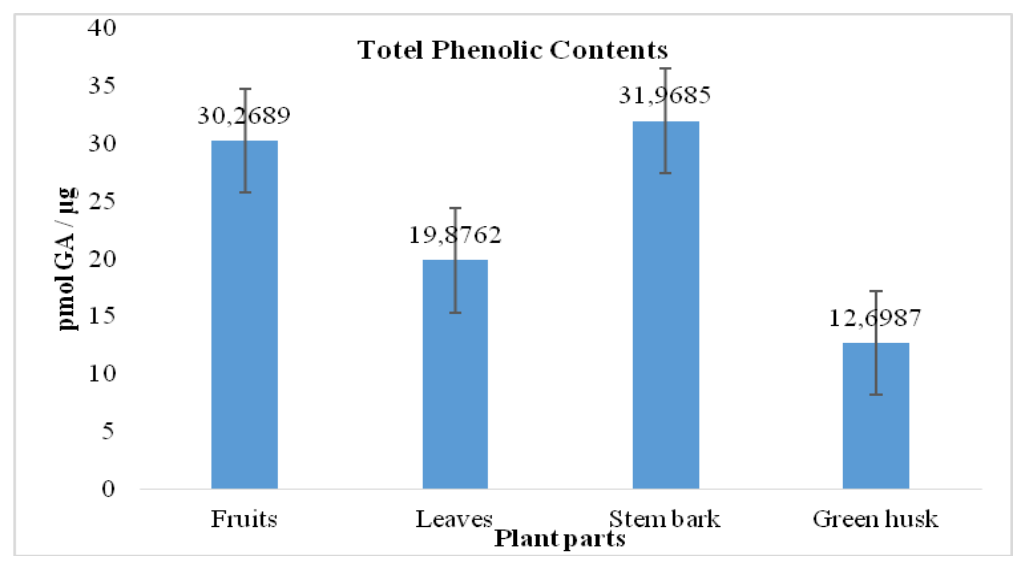

Figure 5. Total phenolic contents of fruits, leaves, stem bark and green husk of J. regia

\section{Flavonoid contents in the methanolic extracts of four parts of Juglans regia}

The total flavonoid contents in the methanolic extracts of the all selected parts of $J$. regia are tabulated in Table 5.

Table 5. Total flavonoid contents of J. regia (methanolic extracts of fruits, leaves, stem bark and green husk)

\begin{tabular}{c|c|c|c|c}
\hline$\#$ & Part used & Conc. Used & Absorbance & (mg of Rutin $\mathbf{g}^{-1}$ of extract) \\
\hline 1 & Fruits & $10 \mu \mathrm{L}$ & 0.49 & $25.8231_{\mathrm{a}} \pm 2.32$ \\
2 & Leaves & $10 \mu \mathrm{L}$ & 0.170 & $7.2861_{\mathrm{c}} \pm 1.15$ \\
3 & Stem bark & $10 \mu \mathrm{L}$ & 0.315 & $17.2896_{\mathrm{b}} \pm 2.88$ \\
4 & Green husk & $10 \mu \mathrm{L}$ & 0.298 & $15.9864_{\mathrm{b}} \pm 2.33$ \\
\hline
\end{tabular}


The highest contents were found in the fruit's extract $25.8231 \mathrm{mg} \mathrm{g}^{-1}$ and lowest value in leave's extract of $J$. regia i.e. $7.2861 \mathrm{mg} \mathrm{g}^{-1}$ (Fig. 6). The plant extract usually containing flavonoids and phenols has already been reported to possess promising biological activities (Maria et al., 2014).

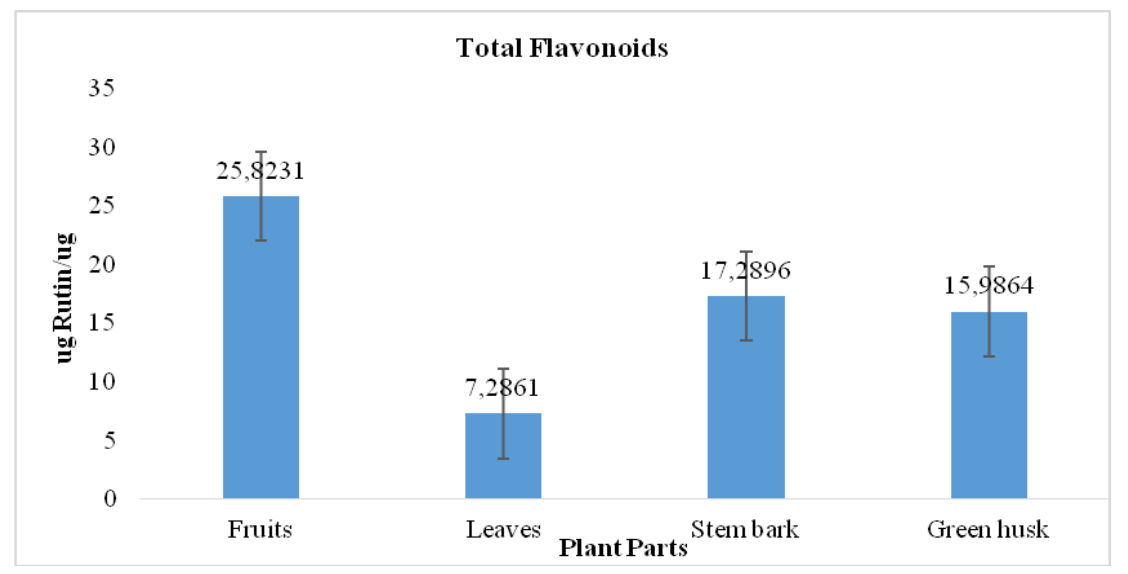

Figure 6. Total flavonoid contents of fruits, leaves, stem bark and green husk of J. regia

\section{Anticancer activity of four parts of J. regia}

Juglans regia fruits, leaves, stem bark and green husk extracts were evaluated for anti-cancer activity in MCF-7 cell line using the MTT assay against the human breast cancer. The (Growth inhibition) $\mathrm{GI}_{50}$ value of all four extracts of Juglans were calculated in $0.5 \mathrm{mg} \mathrm{mL}^{-1}$ and $1 \mathrm{mg} \mathrm{mL}^{-1}$ concentrations. $\mathrm{GI}_{50}$ value gave an indication of the potency of each plant extracts as shown in Table 6 and Figure 7.

Juglans green husk extract at concentrations of $0.5 \mathrm{mg} / \mathrm{mL}$ and $1 \mathrm{mg} / \mathrm{mL}$ exhibited a strong anticancer effect which depicted that only $7 \%$ and $14 \%$ of the cells were alive and $93 \%$ and $86 \%$ cells were damaged, respectively.

$J$. regia green husk proved valuable potential that could enhance cytotoxicity against MCF-7 breast cancer and could be used as therapy against breast cancer. Tested crude extract had medicinal advantages not only for MCF-7 cell line but found to be potent against other type of cancer also. Similar studies have been carried out by Hasan et al. (2011) and Alshatwi et al. (2012) which suggested that green husks and root bark extracts of walnut brought apoptosis in MDA-ME231 human breast cancer and prostate cancer cell lines PC-3 by up-regulating bax gene, caspase 8 and caspase 3 expression and down-controlling Bcl-2 gene expression. Methanolic extract of Stem bark of $J$. regia conferred sensitivity as $10 \%$ and $25 \%$ against tested cell lines at concentration of $0.5 \mathrm{mg} \mathrm{mL}^{-1}$ and $1 \mathrm{mg} \mathrm{mL}^{-1}$ whereas $90 \%$ and $75 \%$ alive cells were recorded. Study of Sanchez-Gonzalez et al. (2014) also suggested that consumption of walnuts could help to reduce the risk of developing cancer. The extract of walnut fruits exhibited significant activity at concentration in $0.5 \mathrm{mg} \mathrm{mL}^{-1}$ that were $33 \%$ cancer cell were alive and $67 \%$ cell damaged, at $1 \mathrm{mg} \mathrm{mL}^{-1}$ concentration only $2 \%$ cancer cell were observed alive and $98 \%$ were damaged.

The walnut fruit extract was assessed against MCF-7 cells line. The extract demonstrated a dosage dependent inhibition effect. $1 \mathrm{mg} / \mathrm{mL}$ concentration conferred best anti-proliferative property as compared to $0.5 \mathrm{mg} / \mathrm{mL}$ concentration of the extract used. Oguzhan and Zeynep (2016) also reported anticancer activity of walnut fruit 


$$
-2318-
$$

against MCF-7 cells. Anticancer potential of leaves extract of Juglans regia at concentration $0.5 \mathrm{mg} / \mathrm{mL}$ recorded as $24 \%$ cells were alive and $76 \%$ cells were damaged, at $1 \mathrm{mg} / \mathrm{mL}$ concentration only $12 \%$ cancer cell were observed alive and $88 \%$ were damaged.

The leaves crude extract of $J$. regia was found to be more powerful against tested cancer cells that may reduce malignancy cells by means of suppression of the p65 phosphorylation, which is supposed to be safe component to reduce malignant disease in cells. Early finding of Taghizadeh et al. (2011) also suggested that plants extract showed higher cytotoxicity potential against MCF-7 cells which was in harmony with current study.

Table 6. Anticancer activity of J. regia (methanolic extracts of fruits, leaves, stem bark and green husk)

\begin{tabular}{c|c|c|c}
\hline$\#$ & Part used & $\mathbf{G I}_{\mathbf{5 0}}$ at $\mathbf{0 . 5} \mathbf{~ m g} / \mathbf{m L}$ & $\mathbf{G I}_{\mathbf{5 0}}$ at $\mathbf{1} \mathbf{~ m g} \mathbf{m L}$ \\
\hline 1 & Fruits & 32.51318 & 1.581722 \\
2 & Leaves & 23.6417 & 11.89427 \\
3 & Stem bark & 90.15817 & 74.69244 \\
4 & Green husk & 6.821963 & 13.47754 \\
\hline
\end{tabular}

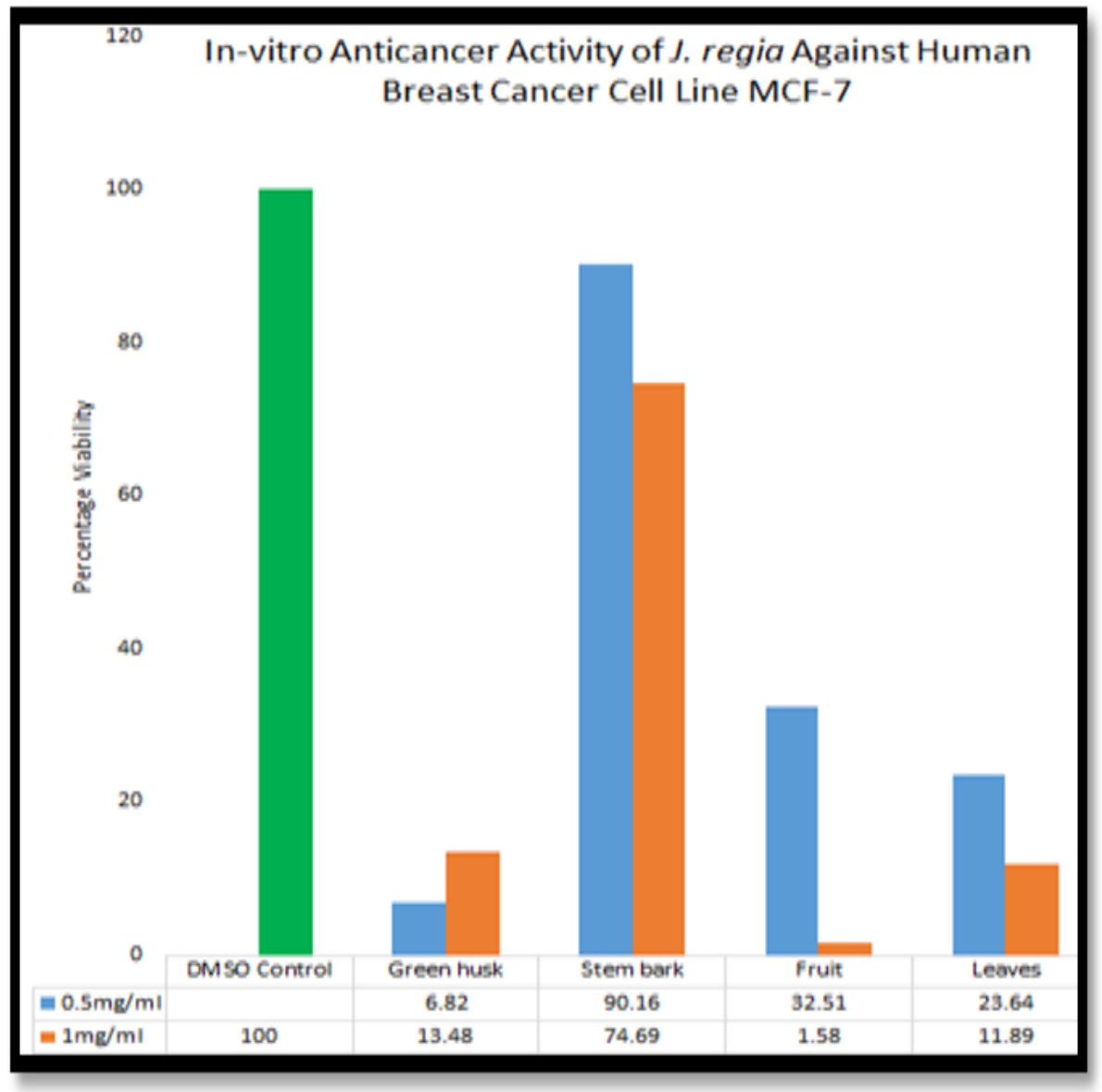

Figure 7. Anticancer activity of J. regia methanolic extracts of fruits, leaves, stem bark and green husk 


\section{Conclusion}

Present investigations concluded that dietary and medicinal plants should be analyzed for metal contamination before use. The results of toxic metal contamination in J. regia indicated that the contaminations of Cd were above SPLs in fruit of J. regia whereas $\mathrm{Zn}$ was below the SPLs. Therefore, these results should be used as important guidelines for the producers, traders, consumers and regulatory authorities to assure the recommended amount of metals in this important dietary fruit by focusing on soil conditions of walnut growing area. Moreover this medicinal plant was proved as potential source of anti-cancer, anti-microbial, anti-oxidant activity. The compounds like phenolic and flavonoids found in different parts of walnut may be used as food supplement and in pharmaceutical industry to cure fatal ailments after detail study both in vivo and in vitro.

\section{REFERENCES}

[1] Alshatwi, A. A., Hasan, T. N., Shafi, G., Syed, N. A. (2012): Validation of the antiproliferative effects of organic extracts from the green husk of Juglans regia L. on PC-3 human prostate cancer cells by assessment of apoptosis-related genes. - Evid. Based Complement Alternat. Med. 2012: 1-8. http://dx.doi.org/10.1155/2012/103026.

[2] Amaral, J. S., Casal, S., Pereira, J. A., Seabra, R. M., Oliveira, B. P. P. (2003): Determination of sterol and fatty acid compositions, oxidative stability, and nutritional value of six walnuts (Juglans regia L.). Cultivars grown in Portugal. - J. Agri. Food Chem. 51(26): 7698-7702.

[3] Amarowicz, R., Troszynska, A., Baryłko-Pikielna, N., Shahidi, F. (2004b): Polyphenolics extracts from legume seeds: correlations between total antioxidant activity, total phenolics content, tannins content and astringency. - J. Food Lipids 11(4): 278-286.

[4] Anwar, F., Kalsoom, U., Sultana, B., Mustaq, M., Mehmood, T., Arshad, H. A. (2013): Effect of Drying method and extraction solvent on the total phenolic and antioxidant activity of cauliflower (Brassica oleracea L.) extracts. - Int. Food Res. J. 20(2): 653-659.

[5] Aruoma, O. I. (1998): Free radicals oxidative stress and antioxidants in human health and disease. - J. Am. Oil Chem. Soci. 75(2): 199-212.

[6] Baytop, T. (1999): Therapy with Medicinal Plants in Turkey (Past and Present). 2nd ed. Nobel Medicine Publisher, Istanbul.

[7] Cohen, M. L. (1992): Epidemiology of drug resistance: Implications for a post antimicrobial era. - Sci. 5073(257): 1050-1055.

[8] Cui, Y. J., Zhu, Y. G., Zhai, R. H., Chen, D. Y., Huang, Z. H., Qiu, Y. (2004): Transfer of metals from soil to vegetables in an area near a smelter in Nanning, China. - Environ. Int. 30: 785-91.

[9] Fatima, M., Wurster, M., Schroder, G., Lindequist, U. (2007): Antioxidant, antimicrobial and cytotoxic activities of selected medicinal plants from Yemen. - J. Ethnoph. 111: 657666.

[10] Gutmann, L., Billot, K. D., Williamson, R., Goldstein, F. W., Mounier, J., Acar, J. F. (1998): Mutation of Salmonella paratyphi conferring cross resistance to several groups of antibiotics by decreased permeability and loss of invasiveness. - Antimicrob. Agents Chemother. 32(2): 195-201.

[11] Hasan, T. N., Shafi, B. L. G., Al-Hazzani, A. A., Alshatwi, A. A. (2011): Antiproliferative effects of organic extracts from root bark of Juglans regia L. (RBJR) on MDA-MB-231 human breast cancer cells: role of Bcl-2/Bax, caspases and Tp53. - Asian Pac. J. Cancer Prev. 12(2): 525-530. 
[12] Jimoh, F. O., Sofidiya, M. O., Afolayan, A. J. (2007): Antioxidant properties of the methanol extracts from the leaves of Paullinia pinnata. - J. Med. Food 10(4): 707-711.

[13] Kachenko, A., Singh, G. B. (2006): Heavy metals contamination in vegetables grown in urban and metal smelter contaminated sites in Australia. - Water, Air, and Soil Pollution 169: 101-123.

[14] Liu, L., Li, K., Koike, W., Zhang, S., Nikaido, T. (2004): New alpha tetralonyl glucosides from the fruit of Juglans mandshurica. - Chem. Pharm. Bull. Tokyo 52(5): 566-569.

[15] Maria, G. M., Susana, N., Susana, A. D., Ana, M. C., Maria, D. A. (2014): Phenols, flavonoids and antioxidant activity of aqueous and methanolic extracts of propolis (Apis mellifera L.) from Algarve, South Portugal. - Food. Sci. Tech. 34(1): 16-23.

[16] Mehmood, A., Murtaza, G., Nasir, M. (2013): Antibacterial and antifungal activity of Dodonaea viscosa (L.) Jacq., a wild plant of Azad Jammu and Kashmir. - Int. J. Biosci. 9(3): 1-7.

[17] Mouhajir, F., Hudson, J. B., Rejdali, M., Towers, G. H. N. (2008): Multiple antiviral activities of endemic medicinal plants used by Berber people of Morocco. - Pharm. Biol. 39(5): 364-374.

[18] Naika, R., Supriya, M. V., Chandrashekar, M. B. (2012): Phytochemicals and Antimicrobial activity of Solanum xanthocarpum Schrad and Wendll. - Res. Rev. Biomed. Biotechnol. 3(2): 9-15.

[19] Noumi, E., Snoussi, M., Hajlaoui, H., Valentin, E., Bakhrouf, A. (2010): Antifungal properties of Salvadora persica and Juglans regia L. extracts against oral Candida strains. Europ. J. Clinical Microbio. - Infectious Dis. 29(1): 81-88.

[20] Oguzhan, D., Zeynep, B. D. (2016): Evaluation of the selective anticancer potential and the genetic mechanisms of the induction of apoptosis by walnut milk in human breast and prostate cancer cells. - Biomed. Res. 27(1): 268-278.

[21] Parekh, J., Chanda, S. V. (2007): In vitro Antimicrobial activity and phytochemical analysis of some Indian medicinal plants. - Turk. J. Biol. 31: 53-58.

[22] Peschel, W. F., Sanchez-Rabaneda, Dieckmann, W., Plescher, A., Gartzia, I. (2005): An industrial approach in the search of natural antioxidants from vegetable and fruits wastes. - Food Chem. 97(1): 137-150.

[23] Piccolella, S., Fiorentino, A., Pacifico, S., Abrosca, B. D., Uzzo, P., Monaco, P. (2008): Antioxidant properties of sour cherries (Prunus cerasus L.): role of colorless phytochemicals from the methanolic extract of ripe fruits. - J. Agri. Food Chem. 56(6): 1928-35.

[24] Recio, M. C., Rios, J. L. (1989): A review of some antimicrobial compounds isolated from medicinal plants reported in the literature. - Phytother. Res. 3: 117-125.

[25] Saeed, N., Khan, M. R., Shabbir, M. (2012): Antioxidant activity, total phenolic and total flavonoid contents of whole plant extracts Torilis leptophylla L. BMC Complem. Altern. Med. 221: 2-12. DOI: 10.1186/1472-6882-12-221.

[26] Salar, R. K., Suchitra (2009): Evaluation of antimicrobial potential of different extracts of Solanum xanthocarpum Schrad and Wendl. - Afr. J. Microbiol. 3(3): 097-100.

[27] Sanchez-Gonzalez, C., Ciudad, C. J., Noe, V., Izquierdo-Pulido, M. (2014): Walnut polyphenol metabolites, urolithins $\mathrm{A}$ and $\mathrm{B}$, inhibit the expression of the prostate-specific antigen and the androgen receptor in prostate cancer cells. - Food Funct. 25(11): 2922.

[28] Scorzoni, L., Benaducci, T., Almeida, A. M. F., Silva, D. H. S., Bolzani, V. S., Gianinni, M. J. (2007): The use of standard methodology for determination of antifungal activity of natural products against medical yeasts Candida sp. and Cryptococcus sp. - Braz. J. Microbiol. 38(3): 391-397.

[29] Silver, L. L., Bostian, K. A. (1993): Discovery and development of new antibiotics: the problem of antibiotic resistance. - Antimicrob. Agents Chemother. 37(3): 377-383.

[30] Singh, A., Sharma, R. K., Agrawal, M., Marshall, F. M. (2009): Health risk assessment of heavy metals via dietary intake of foodstuffs from the wastewater irrigated site of a dry tropical area of India. - Int. Society Trop. Eco. 51(2): 375-387. 
[31] Steel, R. G. D., Torrie, J. H. (1980): Principle and Procedures of Statistics, pp. 287-294. McGraw-Hill, New York.

[32] Tagarelli, G., Tagarelli, A., Piro, A. (2010): Folk medicine used to heal malaria in Calabria (southern Italy). - J. Ethnobiol. Ethnomed. 6: 27.

[33] Taghizadeh, R. S. Z., Mahmoudi, M., Ahi, A., Emami, S. A. (2011): Antiproliferative effects of extracts from Iranian Artemisia species on cancer cell lines. - Pharm. Biol. 49: 962-969.

[34] Tortora, G. J., Funke, B. R. (2001): Microbiology: An Introduction. - Benjamin Cummings, San Francisco.

[35] Vaidyaratnam, P. S. V. (2005): Indian Medicinal Plants a Compendium of 500 species, pp. 264-265. - Orient Longman Private Limited, Chennai. 